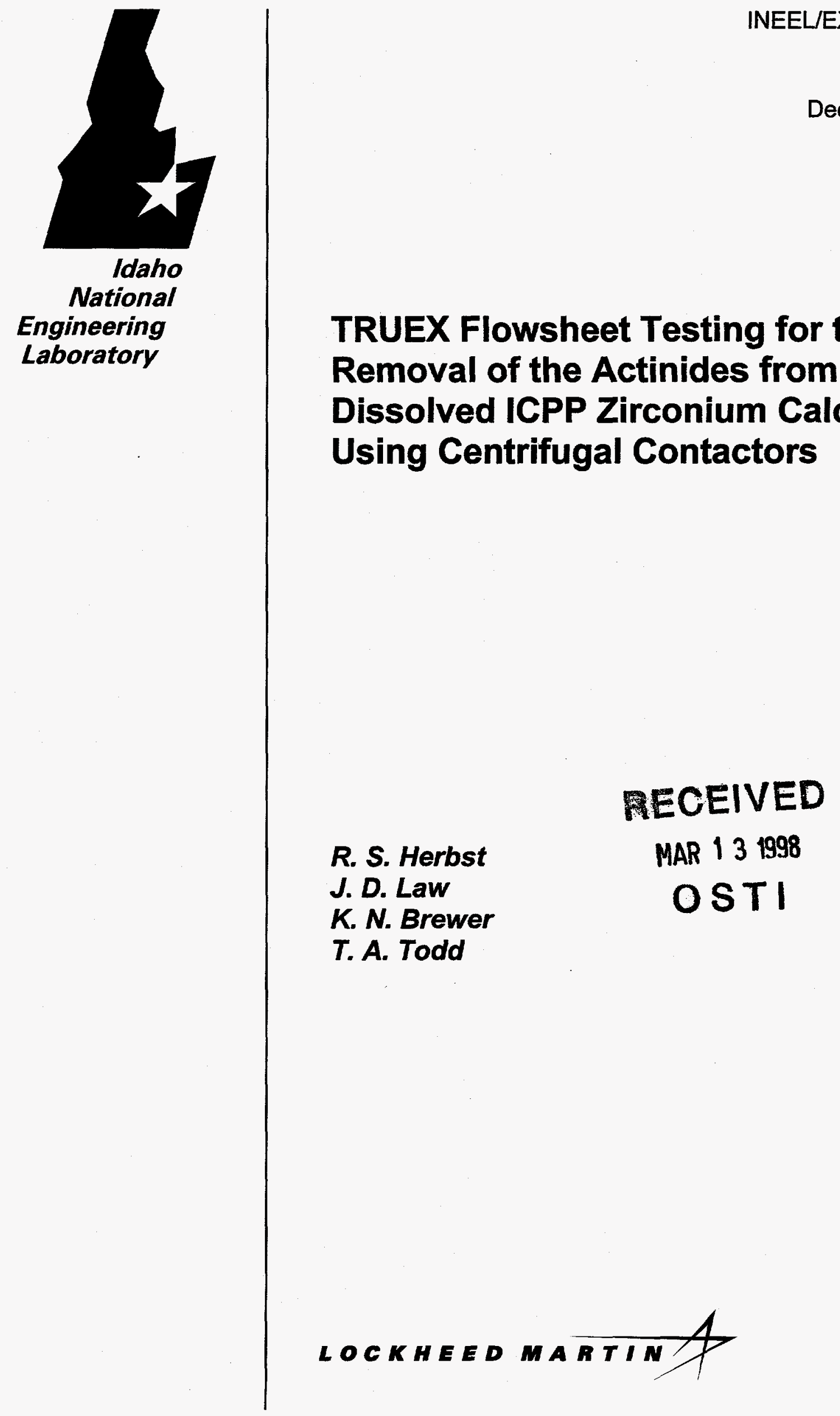




\section{DISCLAIMER}

This report was prepared as an account of work sponsored by an agency of the United States Government. Neither the United States Government nor any agency thereot, nor any of their employees, makes any warranty, express or implied, or assumes any legal liability or responsibility for the accuracy, completeness, or usetuiness of any information, apparatus. product or process disclosed. or represents that its use would not infringe privately owned nights. Peferences herein to any specitic commercial product. process, or service by trade name, trademark, manufacturer, or otherwise, does not necessarily constitute or imply its endorsement, recommendation, or favoring by the United States Govemment or any agency thereot. The views and opınions of authors expressed herein do not necessarily state or reflect those of the United States Government or any agency thereof. 


\title{
TRUEX Flowsheet Testing for the Removal of the Actinides from Dissolved ICPP Zirconium Calcine Using Centrifugal Contactors
}

\author{
R. S. Herbst \\ J. D. Law \\ K. N. Brewer \\ T. A. Todd \\ Published December 1997 \\ Idaho National Engineering Laboratory

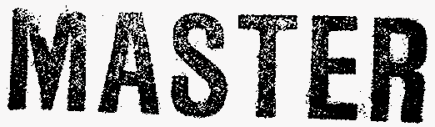 \\ High Level Waste Program \\ Lockheed Martin Idaho Technologies Company \\ Idaho Falls, Idaho 83415
}

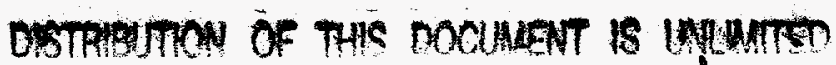

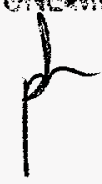

Prepared for the

U.S. Department of Energy

Assistant Secretary for

Environmental Management

Under DOE Idaho Operations Office

Contract DE-AC07-94ID13223 


\section{DISCLAIMER}

Portions of this document may be illegible electronic image products. Images are produced from the best available original document. 


\begin{abstract}
The TRansUranic EXtraction process (TRUEX) is being evaluated for the treatment of Idaho Chemical Processing Plant (ICPP) wastes. The treated wastes resulting from the TRUEX and subsequent fission product separation processes is anticipated to be grouted and disposed as non-TRU low-level wastes (LLW). The resulting fractions containing the TRUs and fission products will be vitrified and disposed of as high-level waste (HLW).

Solid calcine is one of the wastes under evaluation for TRU removal by the TRUEX process. The calcine must first be dissolved in nitric acid prior to the removal of TRUs and fission products. Zirconium type calcine (generated from zirconium fuel reprocessing raffinates) comprises the majority of the calcine currently stored at the ICPP. The zirconium calcines average $18.3 \mathrm{wt} \% \mathrm{ZrO}_{2}$ and are anticipated to be the most challenging to treat with regards to TRU removal because of the large zirconium content.

This paper reports the results from a countercurrent flowsheet test performed with a dissolved calcine simulant in a $2-\mathrm{cm}$ centrifugal contactor pilot plant. The simulant was spiked with radioactive ${ }^{241} \mathrm{Am}$ and ${ }^{95} \mathrm{Zr}$ to facilitate analysis and evaluate the behavior of the actinides. Flooding and precipitate formation were observed in the strip section during the flowsheet testing. It is postulated that the flooding occurred as a result of precipitate formation. The precipitate was determined to be $\mathrm{ZrPO}_{4}$ and was likely formed due the excessive amount of $\mathrm{Zr}$ carried into the strip section with the organic phase. Roughly $65 \%$ of the $\mathrm{Zr}$ in the feed was extracted. Of the extracted $\mathrm{Zr}, 15.6 \%$ reported to the strip product and $15.1 \%$ ended up in the organic effluent, indicating the strip section was ineffective at re-extracting $\mathrm{Zr}$. The poor strip section performance was probably due to the precipitation and concomitant flooding problems encountered in the test, resulting in the strip section never achieving steady state operating conditions. Despite the obvious problems encountered during the test, $>99.18 \%$ of the americium was removed from the feed in the extraction section. This may be slightly lower than the anticipated $99.9 \%$ Am removal efficiency necessary to insure the $<10 \mathrm{nCi} / \mathrm{g}$ TRU content in the LLW raffinate.

Comparison of results from previous tests with those obtained in this experiment is indicative that the operating envelope in this specific flowsheet may be too narrow to meet the desired objectives. Consequently, alternative methods for dealing with the problems encountered with TRUEX processing of dissolved $\mathrm{Zr}$ calcine are required. Future experiments are planned to evaluate alternative dissolution methods and the use of citric acid for feed adjustment and as a scrub solution.
\end{abstract}




\section{ACKNOWLEDGEMENTS}

The authors would like to acknowledge Carl Lundholm, Earlen Wade, Troy Garn and Rich Tillotson for their assistance with the laboratory testing, operation of the centrifugal contactor pilot plant, chemical makeup and sample preparation.

Many thanks to Kerry Oltmanns and Lee Hinckley of the Radiochemistry Group, Jeff Laug, Duane Lundholm and Dennis Nielson of the Spectrochemical Analysis Group for the expedient and efficient sample analyses.

Without the work and dedication of these people, this test could not have proceeded. 


\section{CONTENTS}

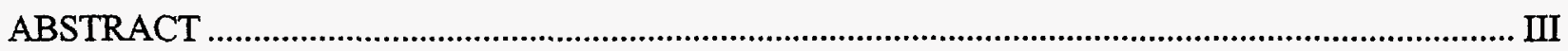

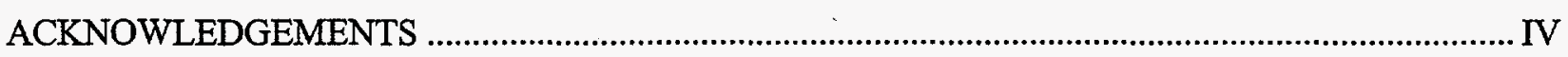

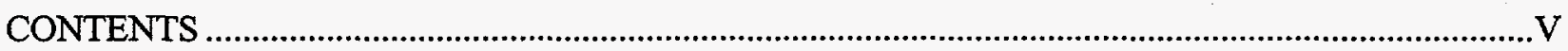

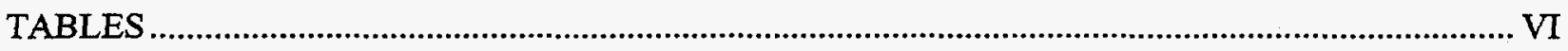

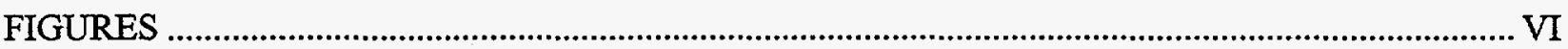

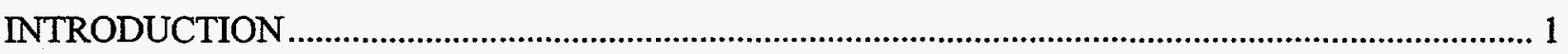

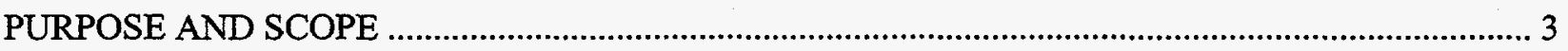

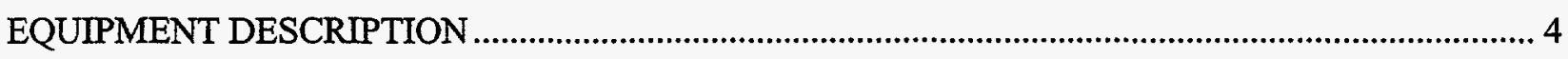

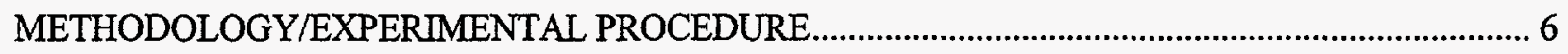

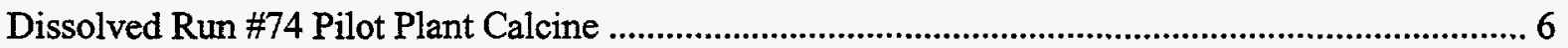

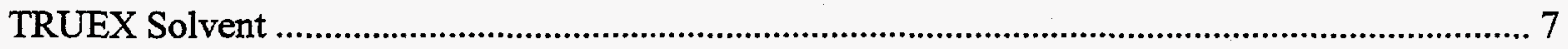

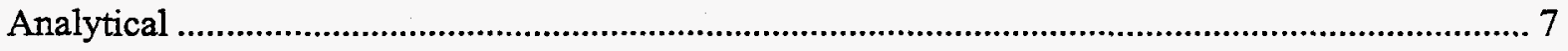

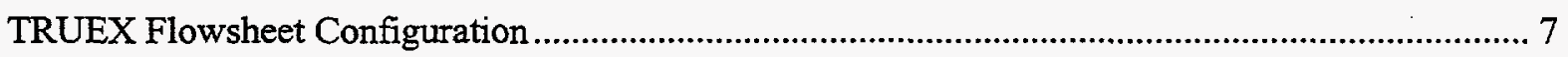

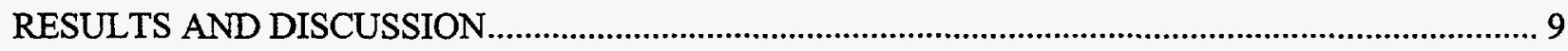

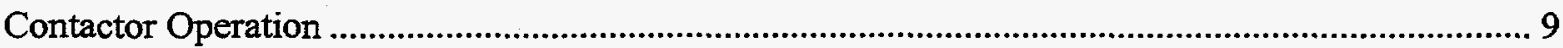

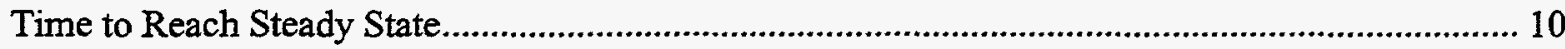

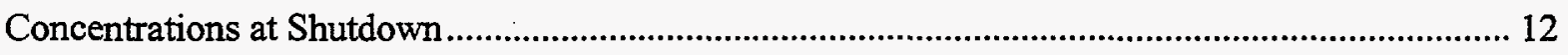

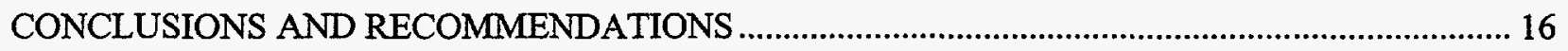

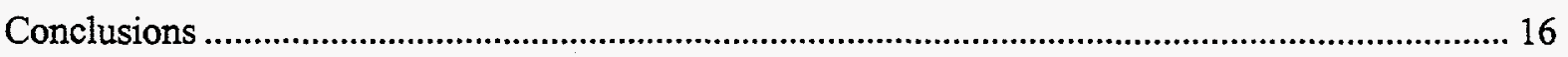

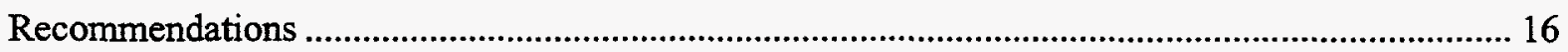

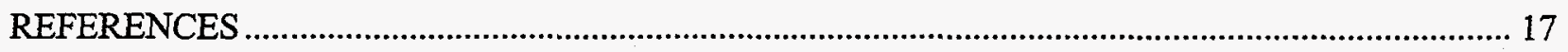

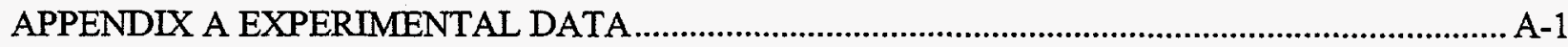




\section{TABLES}

Table 1. Description of the 2-cm centrifugal contactors.

Table 2. Matrix compositions of typical $\mathrm{Zr}$ and Run \#74 calcines and dissolver products...

Table 3. Flowrates and O/A ratios for TRUEX flowsheet testing with dissolved Run \#74 calcine.......10

Table 4. Percentages of components in each of the effluent streams for TRUEX flowsheet testing. ....14

Table 5. Measured stage-wise distribution coefficients from TRUEX flowsheet testing.

Table A-1. Approach to steady state sample concentrations.

Table A-2. Effluent samples taken just prior to shutdown.

Table A-3. Sample data for the individual contactor stages after phase re-equilibration.

\section{FIGURES}

Figure 1. Centrifugal contactors installed in the RAL shielded cell ........................................................5

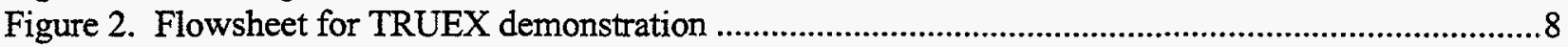

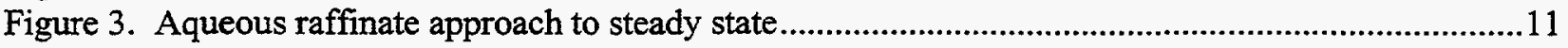

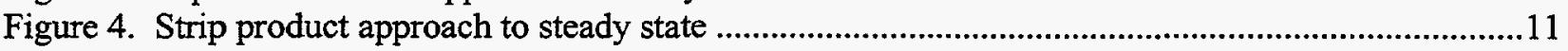

Figure 5. TRUEX flowsheet test concentrations at shutdown..............................................................13 


\section{TRUEX Flowsheet Testing for the Removal of the Actinides from Dissolved ICPP Zirconium Calcine Using Centrifugal Contactors}

\section{INTRODUCTION}

The Idaho Chemical Processing Plant (ICPP), located at the Idaho National Engineering and Environmental Laboratory (INEEL), formerly reprocessed spent nuclear fuel to recover fissionable uranium. The radioactive raffinates from the uranium recovery processes were converted to granular solids (calcine) in a high temperature $\left(500^{\circ} \mathrm{C}\right)$ fluidized bed. Currently, there are $3800 \mathrm{~m}^{3}$ of calcine temporarily stored at the ICPP. The calcine can be characterized as either aluminum type calcine (generated from aluminum fuel reprocessing raffinates) or zirconium type calcine (generated from zirconium fuel reprocessing raffinates). Both calcine types are $<1 \mathrm{wt} \%$ in transuranic (TRU) and fission product content. . A Department of Energy Environmental Impact Statement Record of Decision issued June 1,1995, selected radionuclide partitioning as one of the methods for potential treatment of ICPP liquid and calcine wastes. The aqueous raffinates resulting from the separation processes is anticipated to be grouted and disposed of as non-TRU low-level wastes (LLW). The resulting fractions containing the TRUs and fission products will be vitrified and disposed of as high-level waste (HLW) glass. The primary benefit of the radionuclide partitioning option is a significant HLW glass volume reduction. Based on available data ${ }^{2}$, direct vitrification of the entire $3800 \mathrm{~m}^{3}$ of ICPP calcine would generate approximately $13,000 \mathrm{~m}^{3}$ of HLW glass, while the separation of the TRUs and fission products would result in less than $500 \mathrm{~m}^{3}$ of $\mathrm{HLW}$ glass.

A recent peer review identified the most promising radionuclide separation technologies for evaluation as applied to ICPP wastes. ${ }^{3}$ The TRansUranic EXtraction (TRUEX) process, developed by Horwitz and Schulz ${ }^{4,5}$, was identified as a primary candidate for separation of the actinides from dissolved ICPP calcines. The active extractant used in the TRUEX process solvent is octyl(phenyl)-N,Ndiisobutylcarbamoylmethylphosphine oxide (CMPO). Tributylphosphate (TBP) is added to the solvent as a phase modifier to prevent third phase formation and a paraffinic hydrocarbon is used as a diluent. The TRUEX process has been effectively demonstrated to remove actinides from actual ICPP liquid tank waste using 2-cm diameter centrifugal contactors to well below the $10 \mathrm{nCi} / \mathrm{g}$ NRC Class A low-level TRU waste requirements ${ }^{6,7}$. Efforts are currently underway to develop an equally effective TRUEX flowsheet for the treatment of dissolved ICPP calcines.

The calcine must first be dissolved in nitric acid prior to the removal of TRUs and fission products. The baseline calcine dissolution process uses hot $\left(>95^{\circ} \mathrm{C}\right) 5.0 \mathrm{MHNO}$ at a calcine weight to acid volume ratio of $1 \mathrm{~kg} / 10 \mathrm{~L}$, and the dissolution must occur under vigorous and constant mixing. ${ }^{8}$ Complete calcine dissolution is not accomplished during the dissolution process. However, dissolution studies performed with pilot plant and actual zirconium and aluminum calcines indicate the amount of undissolved solids (UDS) remaining after dissolution will be low, typically 2 to $5 \mathrm{wt} \%$, and that these solids will require disposal with the $\mathrm{HLW} \mathrm{W}^{8,9}$.

Approximately $3000 \mathrm{~m}^{3}$ of the calcine at the ICPP can be characterized as zirconium type calcine. Zirconium calcine types average $18.3 \mathrm{wt} \% \mathrm{ZrO}_{2}$ and are anticipated to be the most challenging to treat with regards to TRU removal because of the large zirconium content. Zirconium has historically been problematic in TRU separation flowsheets because of its tendency to follow the actinides. The extraction of zirconium into the TRUEX solvent can result in undesirable phenomena to occur, including suppressed 
actinide decontamination factors, third phase formation, interfacial crud, or precipitates. The recovery of zirconium with the TRUs may also result in a significant increase in the final HLW glass volume.

Phosphate is also present in the TRUEX high-activity fraction from the use of 1-hydroxyethane-1, 1-diphosphonic acid (HEDPA) as a gross actinide stripping reagent. Phosphate tends to inhibit homogeneous glass forms; therefore, most glasses can only accommodate low phosphate loading. Dilute HEDPA was used as a gross actinide stripping reagent because simultaneous recovery of the actinides is desirable for flowsheet simplification and high-activity waste fraction aqueous volume reduction.

Previous batch contact data were used in conjunction with the Generic TRUEX Model (GTM) to develop a baseline flowsheet for dissolved zirconium calcine that would reduce the amount of phosphate and $\mathrm{Zr}$ reporting to the HLW fraction (strip product). ${ }^{10}$ The proposed flowsheet included a scrub solution comprised of $0.1 \mathrm{MNH}_{4} \mathrm{~F}$ in $1 M \mathrm{MNO}_{3}$ to efficiently back-extract (scrub) $\mathrm{Zr}$ from the solvent and return it to the extraction section. The strip solution was $0.001 M$ HEDPA in $0.01 M \mathrm{HNO}_{3}$, which was sufficient to effectively remove the actinides and metals from the organic while substantially limiting the phosphate in the HLW fraction. The recommended flowsheet was subsequently tested with non-radioactive dissolved calcine simulant in the $5.5 \mathrm{~cm}$ centrifugal contactor mockup at the ICPP. ${ }^{11}$. Non-radioactive neodymium (Nd) was spiked into the simulant as a surrogate for Am to gauge the performance of the flowsheet with respect to actinide behavior. Some results of this test were promising in that operational problems (precipitates, third-phase formation, flooding) were not encountered during the run. However, at the conclusion of the test, a white precipitate was found in the strip section stages. Furthermore, only $\sim 95 \%$ of the Nd was extracted from the feed and $\sim 33 \%$ of the $\mathrm{Zr}$ in the feed reported to the HLW fraction. Additionally, Nd was not efficiently re-extracted from the solvent in the strip section and $\sim 50 \%$ of the extracted Nd reported to the HLW fraction, with the other half remaining in the organic phase. ${ }^{11}$

Preliminary data from the dissolution of actual ICPP calcines indicates the dissolver solution will contain 100 to $1000 \mathrm{nCi} / \mathrm{g}{ }^{241} \mathrm{Am}$ and 1000 to $7000 \mathrm{nCi} / \mathrm{g} \mathrm{Pu}$ (predominately ${ }^{238} \mathrm{Pu} \&{ }^{239} \mathrm{Pu}$ ). ${ }^{10,11} \mathrm{In}$ order to achieve the desired $<10 \mathrm{nCi} / \mathrm{g}$ in the LLW raffinate, removal efficiencies of $86.7 \%$ to $98.7 \%$ are required for $\mathrm{Am}$ and $98.7 \%$ to $99.8 \%$ for $\mathrm{Pu}$ are required. These removal efficiencies are based on a relative raffinate flow rate of 1.34 (relative to the feed flow rate), to reflect dilution of the feed by the scrub in the TRUEX flowsheet. Due to the +3 valence of americium in the feed, this component is the most difficult of the actinides to remove in the TRUEX process. Therefore, ${ }^{241} \mathrm{Am}$ is anticipated to be the primary alpha contributor to the LLW raffinate. Preliminary estimates indicate that if $>99.9 \%$ of the americium can be removed from the feed, the remaining TRU activity will be negligible and the LIW fraction will be well below the $10 \mathrm{nCi} / \mathrm{g}$ limit. ${ }^{11}$

This paper reports the results from TRUEX flowsheet testing performed with a dissolved calcine simulant in a $2-\mathrm{cm}$ centrifugal contactor pilot plant. The centrifugal contactors are located in the Remote Analytical Laboratory hot cell at the ICPP, allowing easy and effective use of radioactive tracers in the test. The flowsheet evaluated in this experiment was recommended from laboratory tests and GTM evaluation and reflects minor modifications to the previously described tests. ${ }^{11}$ Radioactive ${ }^{241} \mathrm{Am}$ and was spiked into the simulated feed to measure the effectiveness of actinide partitioning. Slight modifications to the composition of the scrub and strip solutions were made in an attempt to optimize actinide recovery while reducing the amount of $\mathrm{Zr}$ and phosphate in the HLW fraction. 


\section{PURPOSE AND SCOPE}

Two criteria that must be satisfied by the TRUEX process as applied to $\mathrm{Zr}$ calcine are: 1) the aqueous raffinate must be below the $10 \mathrm{nCi} / \mathrm{g}$ TRU limit specified in $10 \mathrm{CFR} 61.55$; and 2) minimize the final HLW glass volume by decreasing the quantity of inert elements in the high level fraction. Extensive laboratory testing was performed in order to recommend a TRUEX flowsheet that would meet these two goals. ${ }^{10}$ The purpose of this work was simply to evaluate the performance of the proposed flowsheet with the dissolved Run \#74 calcine prior to testing with solutions of actual dissolved radioactive calcine. The scope of this test was to evaluate whether the following conditions could be achieved under continuous counter-current conditions in a $2 \mathrm{~cm}$ centrifugal contactor pilot plant:

1) Determine if the actinide extraction and recovery is sufficient to meet the $10 \mathrm{nCi} / \mathrm{g} \mathrm{LLW}$ criteria. Americium was added to the dissolved Run\#74 pilot plant calcine to evaluate actinide behavior. Cerium, which is sometimes used as a surrogate for americium, is also present in the pilot plant calcine and can be used to gauge the behavior of the actinides and rare earths.

2) Determine the extent of zirconium extraction, how effectively ammonium fluoride would scrub $\mathrm{Zr}$ from the solvent and evaluate the amount of $\mathrm{Zr}$ recovered in the HLW fraction. The scrub solution used for this test was increased from $0.1 M \mathrm{NH}_{4} \mathrm{~F}$ used in previous tests, to 0.2 $M \mathrm{NH}_{4} \mathrm{~F}$ in $1.0 \mathrm{M} \mathrm{HNO}_{3}$. The purpose of increasing the $\mathrm{F}^{*}$ concentration in the scrub was to remove additional $\mathrm{Zr}$ from the organic prior to stripping. Although the pilot plant calcine solution contains $\sim 14 \mathrm{~g} / \mathrm{L}$ stable $\mathrm{Zr}$, radioactive ${ }^{95} \mathrm{Zr}$ tracer was spiked into the feed to facilitate chemical analysis. Analyzing both the stable and radioactive $\mathrm{Zr}$ concentrations allows a determination whether the ${ }^{95} \mathrm{Zr}$ behavior is representative of the bulk zirconium.

3) Evaluate the consequences of reducing the HEDPA concentration in the strip section to determine if recovery of the extracted species was efficient and whether precipitates occurred. Early laboratory results indicated that $0.04 M$ HEDPA was sufficient to effectively re-extract actinides from the TRUEX solvent. ${ }^{10}$ In order to alleviate the precipitate problems encountered in the previous contactor tests, the strip solution composition was altered to $0.004 M$ HEDPA in $0.02 \mathrm{MHNO}_{3}$.

4) Evaluate the overall physical properties of the system to determine if flooding, precipitation, or interfacial crud formed in any of the various sections of the flowsheet.

5) Modeling efforts based on batch distribution coefficients in the Generic TRUEX Model indicate 20 centrifugal contactor stages in the overall TRUEX-calcine flowsheet will be sufficient to achieve the necessary operation requirements. The scope of this work included verification of the stage requirements. 


\section{EQUIPMENT DESCRIPTION}

Flowsheet testing was performed using 2-cm diameter centrifugal contactors instailed in the CPP$684 \mathrm{RAL}$ shielded hot cell. The 2-cm centrifugal contactors, as shown in Figure 1, consist of 24 stages of $2-\mathrm{cm}$ diameter centrifugal contactors, feed and receiving vessels, feed pumps, and an air purge system for the contactor bearings. The aqueous and organic feed pumps and feed vessels were located inside the shielded cell. The remaining feed pumps and feed vessels were located outside the cell. All of the feed pump controllers were located outside the cell. Non-radioactive solutions used for the flowsheet testing were pumped to the centrifugal contactors through penetrations in the cell wall.

The centrifugal contactors were designed and fabricated by Argonne National Laboratory (ANL). The centrifugal contactors were designed specifically for operation of the TRUEX process with ICPP SBW. The contactors were modified at the ICPP for remote installation and operation in the RAL hot cell. Specifically, a modified support structure was fabricated for the contactors. This support structure is portable to allow the contactors to be moved out of the way when not in operation, contains leveling screws to adjust for unevenness in the cell floor, and can be disassembled into three sections. It was necessary to design the support structure to be disassembled into pieces which would fit through the 12 inch by 22 inch glove box access port into the cell before being re-assembled remotely. The centrifugal contactors were also installed through the access port in groups of four and assembled on the support structure remotely. Lifting bails were installed on each contactor to facilitate remote replacement or inspection of any motor/rotor assemblies. Salient features of the centrifugal contactors are provided in Table 1 .

Solution was fed to the contactors using valveless metering pumps. Surge lines, consisting of 4-inch sections of 1-inch stainless steel tubing, were placed on the outlet of the pumps to dampen surging in the solution flows. Because of the difficulty associated with remote installation, surge lines were not installed for the aqueous and organic feed pumps located in cell. Flowrates were adjusted by controlling the pump speed using a ten-turn potentiometer or by manually adjusting the piston stroke length.

Clear, flexible Teflon ${ }^{\oplus}$ or Teflon ${ }^{\otimes}$ lined Tygon ${ }^{\otimes}$ tubing was used for inlet and outlet connections to the feed and receiving vessels. The feed lines were $1 / 8$ in. o.d. tubing and the product lines were $3 / 8$ in. o.d. tubing.

Table 1. Description of the 2 -cm centrifugal contactors.

\begin{tabular}{ll} 
Size & 2-cm rotor diameter \\
Motor & 115 Volt, $60 \mathrm{~Hz}$ Bodine Model 710 \\
RPM & $3,600 \mathrm{rpm}$ (not adjustable) \\
Material of construction & $304 \mathrm{~L}$ stainless steel \\
Inlet and outlet ports & $3 / 8$ in. o.d. tubing \\
Configuration & $\begin{array}{l}\text { Single stage units which can be configured as } \\
\text { desired. Stages are connected using U- tubes. }\end{array}$ \\
\hline
\end{tabular}




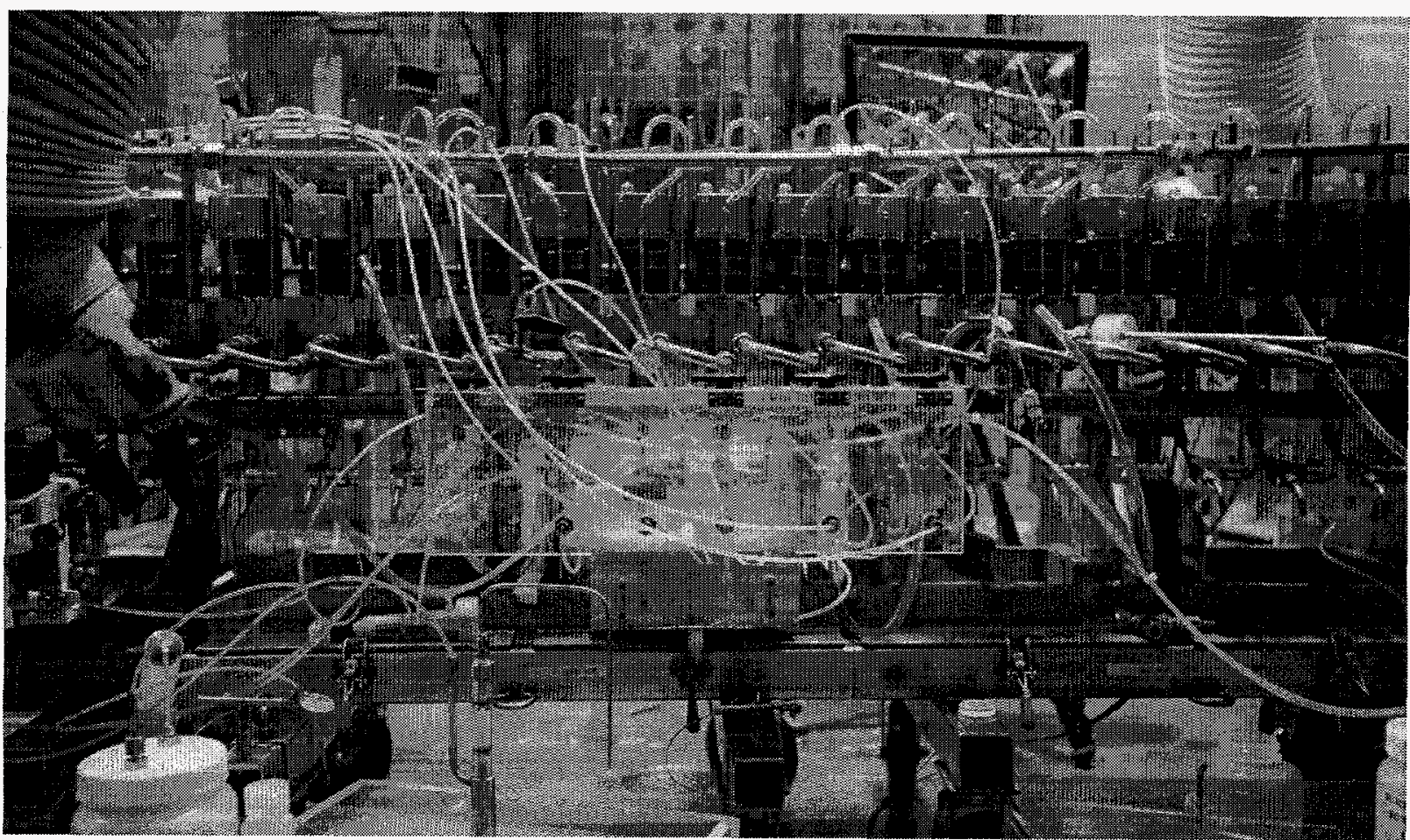

Figure 1. Centrifugal contactors installed in the RAL shielded cell.

The 2-cm centrifugal contactors do not have provisions for sampling the aqueous and organic solutions exiting individual stages during operation. The aqueous raffinate, strip product, and solvent recycle streams were sampled by routing the solution draining to a receiving vessel into a sample bottle during the actual flowsheet test. Individual stage samples were taken by draining the contactor stages after shutdown.

An air purge system was connected to the contactor bearing housings. Purge air was required in order to protect the motor body, shaft, and bearings from corrosive process fumes. Air to the bearing housings passed through a rotameter. The air flowrate through the rotameter could be adjusted from zero to five scfh. Air from the rotameter was split to feed each of the 24 contactors. The diameter of the air manifold was large ( $1 / 2$ in. o.d. tubing), while the diameter of the tubes leading from the manifold to the contactors was small (1/8 in. o.d. tubing), resulting in the air flow to each contactor being approximately equivalent. The offgas from the bearing purge system was vented to the cell. 


\section{METHODOLOGY/EXPERIMENTAL PROCEDURE}

\section{Dissolved Run \#74 Pilot Plant Calcine}

Run \#74 pilot plant calcine was selected as the representative zirconium calcine for use in development testing. The typical composition of solid radioactive $\mathrm{Zr}$ calcine, anticipated dissolver solution from the radioactive calcine, as well as solid and dissolved Run \#74 pilot plant calcine are listed in Table 2. At first glance, the Run \#74 calcine appears to be significantly different that the actual material. Actual $\mathrm{Zr}$ calcine types are varied and the composition may best be represented as a range of values. However, the Run \#74 calcine represents a "worst case" $\mathrm{Zr}$ content, which is important since it is indeed the $\mathrm{Zr}$ which provides the major impediment to the TRUEX process. The ideology is that if the TRUEX flowsheet can be developed to meet the current performance criteria with respect to Run \#74 calcine, it will likely be readily adaptable to all compositions of radioactive $\mathrm{Zr}$ calcine types.

Note that the current baseline dissolution procedure for calcine calls for $10 \mathrm{~L}$ of $5 \mathrm{MHNO} \mathrm{HN}_{3}$ per $1 \mathrm{~kg}$ calcine at near boiling $\left(\sim 95^{\circ} \mathrm{C}\right)$ temperatures for a minimum of 30 minutes. This procedure was used for dissolving the pilot plant calcine to prepare the aqueous feed for development efforts. Approximately 95 to $98 \mathrm{wt} \%$ of the Run \#74 calcine is dissolved under the above dissolution conditions. Finally, early work with dissolved Run \#74 calcine indicated that it was necessary to reduce $\mathrm{Cr}$ from the extractable +6 oxidation state to the inextractable +3 oxidation state for effective use of the TRUEX extraction scheme. Consequently, micro quantities of $\mathrm{H}_{2} \mathrm{O}_{2}$ where added to the feed expressly for the reduction of the chromium oxidation state.

Table 2. Matrix compositions of typical $\mathrm{Zr}$ and Run \#74 calcines and dissolver products.

\begin{tabular}{|c|c|c|c|c|}
\hline \multirow[b]{2}{*}{ Element } & Typical Zr Calcine & $\begin{array}{l}\text { Run \#74 Pilot Plant } \\
\text { Calcine }\end{array}$ & Typical Zr Calcine & $\begin{array}{c}\text { Run \#74 Pilot Plant } \\
\text { Calcine }\end{array}$ \\
\hline & \multicolumn{2}{|c|}{ Wt \% in Calcine Before Dissolution ${ }^{2}$} & \multicolumn{2}{|c|}{ Feed Concentration $(M)$} \\
\hline$\overline{\mathrm{Al}}$ & $\overline{47.3}$ & 11.2 & 0.259 & $\overline{0.42}$ \\
\hline B & 0.73 & 1.1 & 0.064 & 0.068 \\
\hline $\mathrm{Ca}$ & 30.9 & 25.0 & 0.723 & 0.65 \\
\hline $\mathrm{Ce}$ & ND & 0.1 & --- & $4.0 \mathrm{E}-4$ \\
\hline $\mathrm{Cr}$ & 0.26 & 0.4 & -.. & $5.7 \mathrm{E}-3$ \\
\hline $\mathrm{Cs}$ & ND & 0.5 & --- & $4.7 \mathrm{E}-3$ \\
\hline $\mathrm{Fe}$ & 0.37 & 0.1 & $1.6 \mathrm{E}-03$ & 0.013 \\
\hline $\mathrm{K}$ & 0.32 & $<0.1$ & $7.7 \mathrm{E}-03$ & $6.0 \mathrm{E}-4$ \\
\hline Mo & ND & ND & --- & $1.8 \mathrm{E}-4$ \\
\hline $\mathrm{Na}$ & 1.9 & 0.4 & 0.077 & $8.5 \mathrm{E}-3$ \\
\hline $\mathrm{Ni}$ & ND & 0.1 & 0.062 & $1.7 \mathrm{E}-3$ \\
\hline $\mathrm{Pb}$ & ND & $<0.1$ & --- & $<1.9 \mathrm{E}-6$ \\
\hline $\mathrm{Sr}$ & ND & 0.7 & --- & $8.1 \mathrm{E}-3$ \\
\hline $\mathrm{Zr}$ & 11.3 & 16.6 & 0.108 & 0.21 \\
\hline $\mathrm{Cl}^{-}$ & 0.10 & $<0.2$ & $4.7 \mathrm{E}-03$ & $<0.088$ \\
\hline $\mathrm{F}^{-}$ & 25.7 & 17.4 & 1.27 & 0.89 \\
\hline $\mathrm{H}^{+}$ & NA & NA & 3.05 & 3.5 \\
\hline $\mathrm{NO}_{3}^{-}$ & 4.09 & $<0.1$ & 4.77 & 6.0 \\
\hline $\mathrm{PO}_{4}^{-3}$ & ND & ND & --- & ND \\
\hline $\mathrm{SO}_{4}^{-2}$ & ND & 5.4 & --- & 0.050 \\
\hline Density $\mathrm{g} / \mathrm{cm}^{3}$ & 1.6 & ND & 1.26 & 1.2 \\
\hline
\end{tabular}

${ }^{\mathrm{a}}$ Remainder of mass balance is oxygen

$\mathrm{ND}=$ Not Determined 


\section{TRUEX Solvent}

The composition of the TRUEX solvent used in these tests was $0.2 M$ CMPO and 1.4 $M$ TBP in Isopar L ${ }^{\circledR}$. The solvent was prepared by the ICPP Quality Control Laboratory and was used previously for flowsheet development studies in $2.0-\mathrm{cm}$ and $5.5-\mathrm{cm}$ centrifugal contactor mockups. The purity and composition of the TRUEX solvent were established prior to use in the centrifugal contactors. Impurities in the CMPO, resulting from acid hydrolysis, radiolytic degradation, or residual manufacturing impurities, may hinder the ability to strip the actinides from the TRUEX solvent. ${ }^{12}$ The distribution coefficient for

${ }^{241} \mathrm{Am}$ is particularly sensitive to CMPO impurities. Therefore, the distribution coefficient for ${ }^{241} \mathrm{Am}$ was evaluated as a function of nitric acid concentration from $\mathrm{HNO}_{3}$ solutions to evaluate CMPO purity and solvent composition. This method of determining ${ }^{241}$ Am distributions as a function of nitric acid concentration was established as a quality control procedure and was used to test the initial TRUEX solvent and the solvent after each flowsheet test. ${ }^{13}$ If the results were comparable to literature values, the solvent was suitable for extraction studies.

\section{Analytical}

Samples from testing were analyzed for total $\mathrm{Zr}$ and ${ }^{95} \mathrm{Zr},{ }^{241} \mathrm{Am}, \mathrm{Ce}, \mathrm{Cr}, \mathrm{Fe}$, and $\mathrm{H}^{+}$. Inductively Coupled Plasma Emission Spectroscopy (ICP-ES) was used for total $\mathrm{Zr}, \mathrm{Ce}, \mathrm{Cr}$, and $\mathrm{Fe}$ analyses. Gamma spectroscopy was used for ${ }^{241} \mathrm{Am}$ and ${ }^{95} \mathrm{Zr}$ analyses.

Organic samples could not be directly analyzed for the stable metals $\mathrm{Zr}, \mathrm{Ce}, \mathrm{Cr}$, and $\mathrm{Fe}$. Therefore, 2 $\mathrm{mL}$ aliquots of each organic dilution were contacted with $10 \mathrm{mLs}$ of $0.25 M 1$-hydroxyethane $1,1-$ diphosphonic acid (HEDPA) made up in $0.04 M \mathrm{HNO}_{3}(\mathrm{O} / \mathrm{A}=0.2)$. The resulting aqueous phase was used for analysis of the organic samples. HEDPA has been shown to quantitatively extract $\mathrm{Fe}, \mathrm{Zr}$, and the actinides from the TRUEX solvent. ${ }^{6}$ Direct analysis for ${ }^{95} \mathrm{Zr}$ and ${ }^{241} \mathrm{Am}$ were possible on the organic samples by gamma spectroscopy.

\section{TRUEX Flowsheet Configuration}

Based on experimental results from batch contacts with dissolved pilot plant calcine and modeling efforts with the GTM, a TRUEX flowsheet was recommended for testing in the 2-cm centrifugal contactors using dissolved calcine. This flowsheet is shown schematically in Figure 2 . The flowsheet consists of six extraction stages at an organic to aqueous phase ration (O/A) of 0.75 . The extraction section is followed by four scrub stages with $0.2 \mathrm{MNH}_{4} \mathrm{~F}$ in $1.0 \mathrm{MHNO}_{3}$ at an $\mathrm{O} / \mathrm{A}$ of 2.9. Note that the scrub solution was designed to remove $\mathrm{Zr}$ from the TRUEX solvent and recombine it with the aqueous feed to the extraction section. There are six stripping stages with $0.004 M$ HEDPA in $0.02 M \mathrm{HNO}_{3}$ at an O/A of 1.0. The wash section consists of two stages using $0.25 \mathrm{M} \mathrm{Na}_{2} \mathrm{CO}_{3}$ at an $\mathrm{O} / \mathrm{A}$ of 5.0. Finally, there are two stages of $0.1 \mathrm{M} \mathrm{HNO}_{3}$ rinse at an O/A of 10.0. There is no benefit for the fractionation of individual actinides (i.e., Am from $\mathrm{Pu}$ ) since all the actinides will be disposed of in the high-activity waste glass. Therefore, a gross actinide stripping agent (HEDPA) was used. The concentration of HEDPA was reduced from the typical concentration of $0.04 M$ to $0.004 M$ for this test in order to reduce the quantity of phosphorus in the HLW strip product. The presence of phosphorus in the HLW fraction will increase the quantity of HLW glass product. 


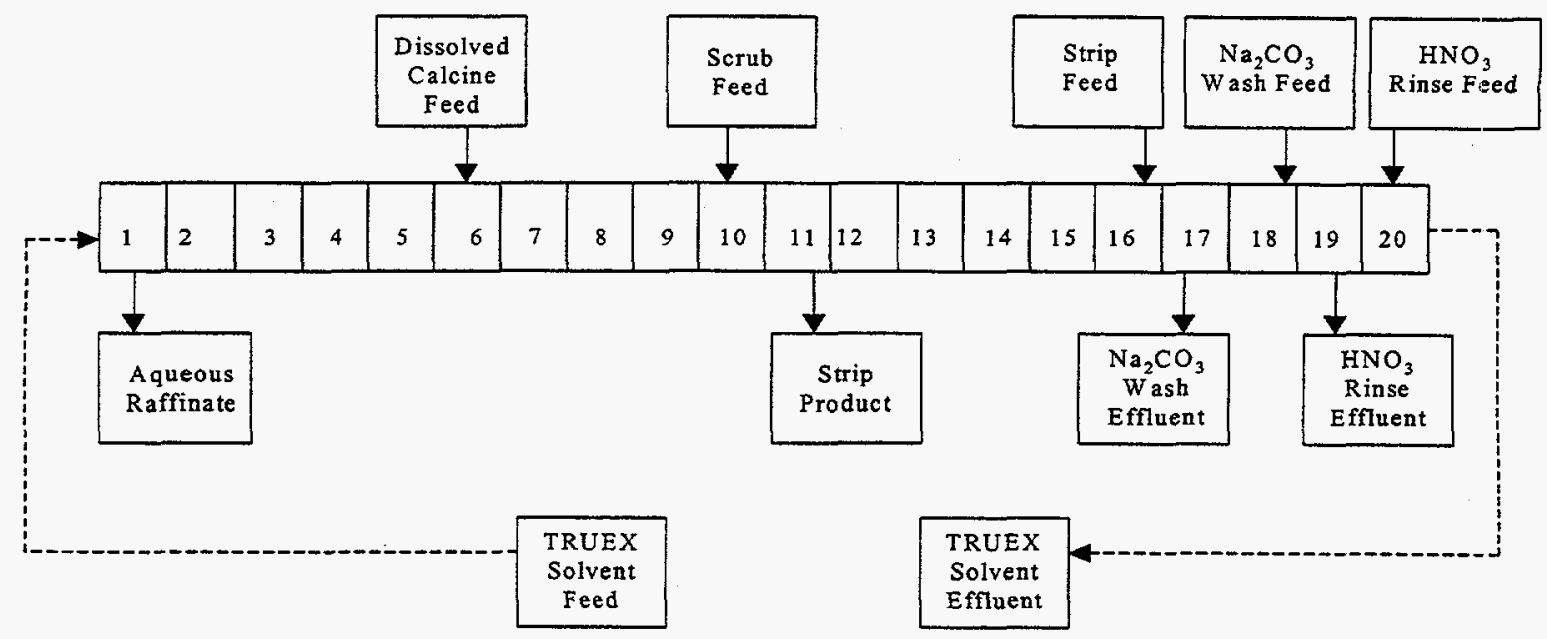

Figure 2. Flowsheet for TRUEX demonstration. 


\section{RESULTS AND DISCUSSION}

\section{Contactor Operation}

Startup and operation of the equipment proceeded as follows: The centrifugal contactor motors were started at 3,600 $\mathrm{rpm}$. All aqueous solution flows, except for the spiked calcine solution, were established. The aqueous feed flow was established using dissolved calcine solution that did not contain the ${ }^{241} \mathrm{Am}$ and

${ }^{95} \mathrm{Zr}$ tracers. Organic flow was started after the aqueous feeds were established. Thirty minutes after the starting the organic feed, the aqueous feed was switched from the unspiked feed to the dissolved calcine containing the ${ }^{95} \mathrm{Zr}$ and ${ }^{241} \mathrm{Am}$ tracers. Samples were taken from the aqueous raffinate and strip product streams at intervals of 30,60 , and 90 minutes after the start of spiked calcine feed. Level readings for each of the feed tanks were also noted in order to determine actual solution flowrates based on tank depletion rates. The actual values are compared to the target flowrates in Table 3 . The data in Table 3 indicate the measured flowrates were all very close to the target values.

The first strip product sample taken after 30 minutes appeared to contain a small, indeterminate amount of organic, indicating some flooding may have been occurring. After taking the first sample, the strip product receiver vessel was checked to determine if organic was apparent in the strip product. This was accomplished by pouring some of the strip product from the receiver vessel to a glass beaker. Organic was not visible on the strip product after the first (30 minute) or second (60 minute) samples were taken. However, the aqueous phase did appear slightly cloudy, an indication some precipitation may have been occurring in the strip section. The strip product sample taken at 90 minutes was definitely flooded, containing $\sim 50$ vol\% organic, and the aqueous phase was cloudy.

Approximately 120 minutes after the start of spiked calcine feed, samples were taken of each product stream, including the organic effluent. The strip product sample still indicated flooding and precipitation problems. The contactors were shut down by simultaneously stopping the feed pumps and contactor motors. Each stage remains approximately at steady-state operating conditions with this type of shutdown. This allowed aqueous and organic samples to be taken from each stage and, therefore, distribution coefficients to be determined for individual stages. After shutdown, the contents of each stage were drained into individual $60 \mathrm{~mL}$ sample bottles. The two phases were re-equilibrated by vigorously mixing (using a vortex mixer) for one minute. Re-equilibration of the phases serves to evaluate distribution coefficients of the individual species under hypothetical conditions of $100 \%$ stage efficiency. The reequilibrated solutions from each stage were then separated and the aqueous and organic phases were submitted for analysis. Because of the apparent flooding problems encountered during the run, only select stage solutions drained from the contactors were submitted for analysis. Stages $1,3,5$, and 6 in the extraction section, stages 7 and 10 in the scrub section, stages 11,13 , and 16 in the strip section, and stages 17 and 19 in the wash and rinse sections, respectively, were submitted for analysis.

Examination of the contactors and the solutions drained from the contactors after shutdown verified the presence of solids formation in the stripping section. White precipitate was observed on the rotor and in the bottom of the contactor housings for stages 11, 12, and 13. It appeared that the greatest amount of solids was in stage 11, the strip product stage, and the amount of solids decreased in stage 12 and 13. Solids were not visually apparent in any of the other stages. The solutions drained from stages $1,3,5,6,7$, and 10 in the extraction and scrub sections were clear and the phases disengaged rapidly under the influence of gravity ( $<5$ minutes). Solutions drained from stages 17 and 19 were also clear and disengaged rapidly. Solutions removed from the strip section contactors contained white solids dispersed throughout both phases. The phases would not separate under gravity and required high-speed centrifugation for phase disengagement. After centrifuging, the precipitate was at the bottom of the tube and small amounts of crud remained at the organic-aqueous interface. Samples of the precipitate were submitted for chemical analysis. The analysis of the solid (by scanning electron microscopy) indicated the major components were $\mathrm{Zr}, \mathrm{O}$, and $\mathrm{C}$. It is postulated that the precipitate is predominately $\mathrm{ZrPO}_{4}$, based on results from similar 
Table 3. Flowrates and O/A ratios for TRUEX flowsheet testing with dissolved Run $\# 74$ calcine.

\begin{tabular}{lcccccc}
\hline \multirow{2}{*}{ Section } & Phase & \multicolumn{2}{c}{ Flowrate $(\mathrm{mL} / \mathrm{min})$} & \multicolumn{2}{c}{ O/A Ratio } & Total Flow \\
\hline All & Org. & 10.0 & 10.1 & -- & -- & -- \\
Extraction & Aq. & 10.0 & 9.6 & 0.75 & 0.78 & 23.1 \\
Scrub & Aq. & 3.4 & 3.4 & 2.9 & 3.0 & 13.5 \\
Strip & Aq. & 10.0 & 9.7 & 1.0 & 1.0 & 19.8 \\
$\mathrm{Na}_{2} \mathrm{CO}_{3}$ & Aq. & 2.0 & 1.8 & 5.0 & 5.6 & 10.9 \\
Wash & & & & & & \\
Acid Rinse & Aq. & 1.0 & 0.97 & 10.0 & 10.4 & 11.1 \\
\hline
\end{tabular}

solids encountered during previous experiments..$^{10}$ Note that phosphorus does not show up in SEM analysis due to the overlap with the $\mathrm{Zr}$ peak and other analytical methods (e.g., X-ray diffraction) are required to resolve between the two elements.

\section{Time to Reach Steady State}

The concentrations of ${ }^{241} \mathrm{Am}$ and ${ }^{95} \mathrm{Zr}$ as a function of time $\left(\mathrm{T}_{0}=\right.$ start of the radionuclide spiked dissolved calcine feed) are given in Figures 3 and 4 for the aqueous raffinate and strip product, respectively. Note that the ${ }^{241} \mathrm{Am}$ activity in the aqueous raffinate was below the analytical detection for all samples. Consequently, there are no meaningful data for Am approach to steady state in the aqueous raffinate. Steady state was assumed when the concentration of the components varied by less than the analytical error associated with the sample analyses. It is apparent from Figure 3 that the extraction section was operating at steady state with regard to ${ }^{95} \mathrm{Zr}$ within the first 30 minutes of operation. The data in Figure 4 indicate that the strip section never achieved steady state operation with respect to ${ }^{241} \mathrm{Am}$ or ${ }^{95} \mathrm{Zr}$. Through the first 90 minutes of operation, the concentrations of $\mathrm{Am}$ and $\mathrm{Zr}$ were increasing in the strip product, as would be expected. However, the concentrations decreased during the last 45 minutes. The fact that the strip section never achieved steady state operation is attributed to the precipitation and flooding problems that were encountered during operation. Recall that flooding became apparent in the 90 minutes strip product sample, the fact that the Am and $\mathrm{Zr}$ concentrations decreased after that time indicates some losses of $\mathrm{Am}$ and $\mathrm{Zr}$ to the precipitate. 


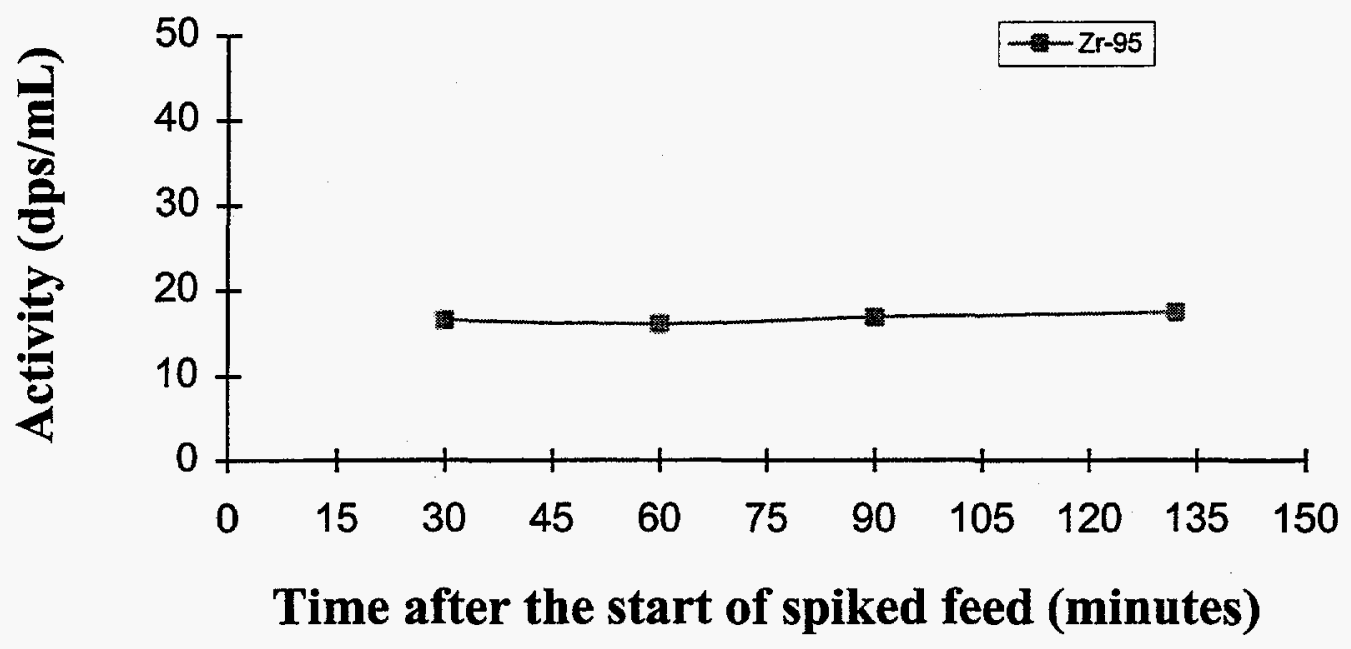

Figure 3. Aqueous raffinate approach to steady state.

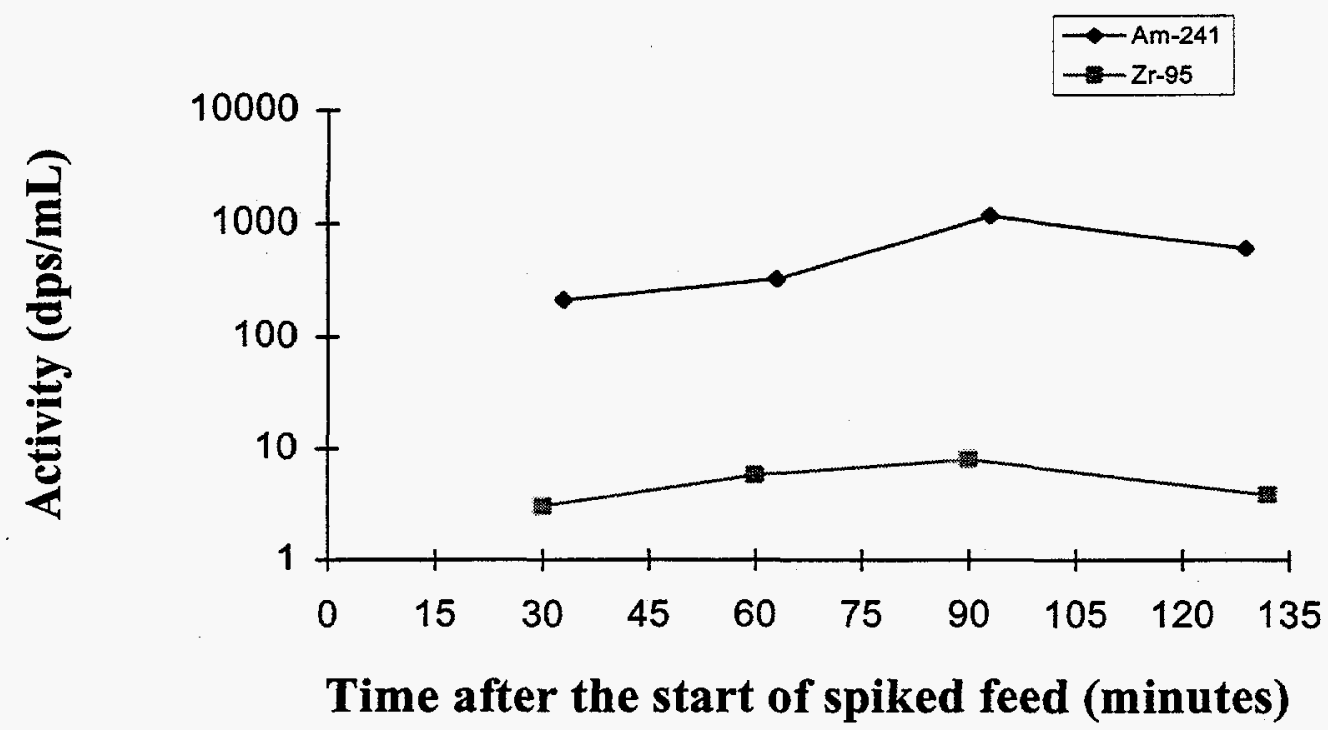

Figure 4. Strip product approach to steady state. 


\section{Concentrations at Shutdown}

The concentrations of ${ }^{241} \mathrm{Am},{ }^{95} \mathrm{Zr}$, total $\mathrm{Zr}, \mathrm{H}^{+}, \mathrm{Fe}, \mathrm{Cr}$, and $\mathrm{Ce}$ in each stream immediately prior to shutdown are given in Figure 5. The percentages of the components in each of the effluent streams and material balances for these components are given in Table 4 . The values in Table 4 were also normalized to obtain an overall material balance of $100 \%$. The material balance data are rather low for ${ }^{241} \mathrm{Am},{ }^{95} \mathrm{Zr}$, and extremely low for Ce. The low material balance data are indicative of losses of these components to the precipitate formed in the strip section. Samples of the precipitate were analyzed to determine if the poor material balances were attributed to losses in the solids. As mentioned previously, the precipitate was determined to be zirconium phosphate, $\mathrm{ZrPO}_{4}$; however, material balance data suggest cerium to be a constituent as well. This discrepancy can be resolved by noticing the large difference between the masses of cerium and zirconium in the feed shown in Table 5. Loosing a small amount of zirconium in the precipitate may not be noticed in the material balance, while loosing a small amount of cerium would be catastrophic to the material balance. The material balance for total $\mathrm{Zr}$ is very good (100.7\%), while that for ${ }^{95} \mathrm{Zr}$ is quite low $(72.1 \%)$. This fact provides another indicator of the dramatic effect losses can have on the material balance due to relative masses of the material. Based on these observations, it is reasonable the precipitate that occurred in the strip section was predominately zirconium phosphate, which carried down cerium and perhaps some americium. The material balances for $\mathrm{Cr}, \mathrm{Fe}$ and acid are somewhat high, but not unreasonable based on analytical errors. It should be noted that the high $\mathrm{Fe}$ and $\mathrm{Cr}$ material balances may have been due to contamination, either from chemical reagents, reuse of the organic solvent, or even degradation (over time) of stainless steel parts used in the mockup.

The activity of ${ }^{241} \mathrm{Am}$ was reduced from $736 \mathrm{dps} / \mathrm{mL}$ in the feed to $<4.48 \mathrm{dps} / \mathrm{mL}$ in the aqueous raffinate. This corresponds to a removal efficiency of $>99.18 \%$. Greater than $82.78 \%$ of the americium was removed from the solvent in the stripping section. The low stripping efficiency is due to the apparent loss of americium in the precipitate as indicated by the poor material balance. Based on the normalized percentages, $98.40 \%$ of the ${ }^{241} \mathrm{Am}$ was recovered in the strip section.

The cerium results were anticipated to be similar to those for americium. Based on the normalized percentages (due to the poor material balance for $\mathrm{Ce}$ ), $95.11 \%$ of the $\mathrm{Ce}$ in the feed was extracted. These results are somewhat lower than those for Am and contain a great deal of uncertainty due to the poor material balance. Only $50.8 \%$ of the extracted Ce was recovered in the strip section. The balance, or: $44.0 \%$, remained in the organic, indicating the strip section was not operating effectively. Although it is difficult too tell from the data, it is possible that the oxidation state of $\mathrm{Ce}$ was +4 rather than +3 , which resulted in different behavior of $\mathrm{Ce}$ than for $\mathrm{Am}^{+3}$.

In earlier testing, $33 \%$ of the $\mathrm{Zr}$ was extracted using a $0.1 M \mathrm{NH}_{4} \mathrm{~F}$ scrub solution. In this test, $30 \%$ to $40 \%$ of the $\mathrm{Zr}$ was extracted from the feed. This comparison indicates there was little benefit in increasing the $\mathrm{NH}_{4} \mathrm{~F}$ concentration in the scrub to enhance $\mathrm{Zr}$ removal from the organic prior to stripping. Of the $\mathrm{Zr}$ that was extracted and carried over to the strip section, approximately half was removed in the strip section. The balance of the extracted $\mathrm{Zr}$ exited the flowsheet with the organic effluent, again indicating the ineffectiveness of the strip section. The experimental data are contained in Appendix $A$, and it is of interest to note there is a discrepancy in the $\mathrm{Zr}$ data from the organic effluent sample and the stage-wise organic samples. The organic effluent contained $2080 \mathrm{ppm} \mathrm{Zr}$, while the organic samples taken from stages 13, 17, and 19 (in the strip wash, and rinse sections, respectively) all contained $<64.8 \mathrm{ppm} \mathrm{Zr}$. This indicates the organic effluent sample contained roughly 100 times more $\mathrm{Zr}$ than was in the organic from the individual stage samples. This discrepancy cannot be explained and it is not possible to re-analyze the organic effluent sample at this point. The data does suggest that the amount of $\mathrm{Zr}$ in the organic effluent is likely significantly lower, which would reduce the percentage of $\mathrm{Zr}$ in the organic effluent, as well as lower the material balance results. The analytical results for the other metals in the organic effluent sample were all comparable to those for the later stage-wise organic samples, with the exception of iron. 


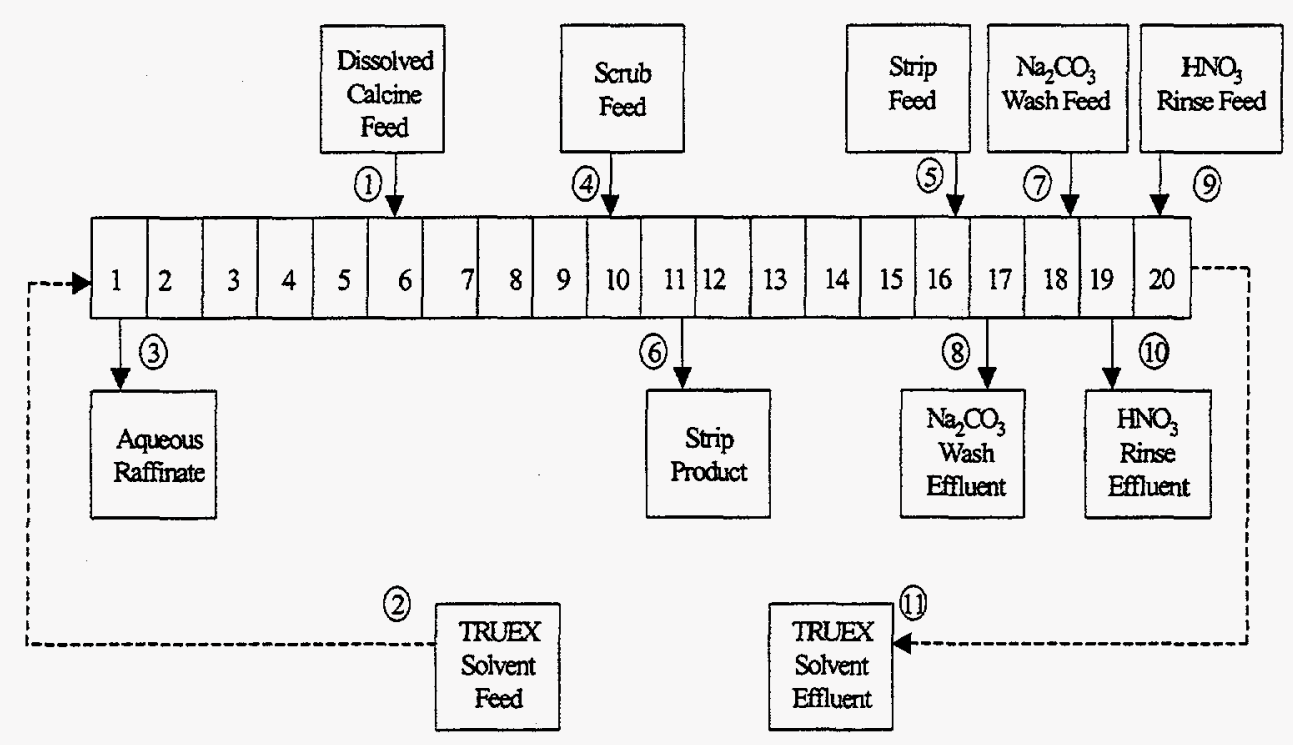

\begin{tabular}{|c|c|c|c|c|c|c|c|c|c|c|c|}
\hline Component & $\begin{array}{c}\text { Calcine } \\
\text { Feed } \\
1\end{array}$ & $\begin{array}{l}\text { TRUEX } \\
\text { Solvent } \\
\text { Feed } \\
2\end{array}$ & $\begin{array}{c}\text { LAW } \\
\text { Raff. } \\
3\end{array}$ & $\begin{array}{c}\text { Scrub } \\
\text { Feed } \\
4\end{array}$ & $\begin{array}{c}\text { Strip } \\
\text { Feed } \\
5\end{array}$ & $\begin{array}{c}\text { Strip } \\
\text { Product } \\
6\end{array}$ & $\begin{array}{c}\mathrm{Na}_{2} \mathrm{CO}_{3} \\
\text { Feed } \\
7\end{array}$ & $\begin{array}{c}\mathrm{Na}_{2} \mathrm{CO}_{3} \\
\text { Effluent } \\
8\end{array}$ & $\begin{array}{c}\text { Acid } \\
\text { Rinse } \\
\text { Feed } \\
9\end{array}$ & $\begin{array}{c}\text { Acid } \\
\text { Rinse } \\
\text { Effluent } \\
10\end{array}$ & $\begin{array}{c}\text { TRUEX } \\
\text { Solvent } \\
\text { Effluent } \\
11\end{array}$ \\
\hline$\overline{\mathrm{H}(M)}$ & 2.86 & $n d^{2}$ & 1.94 & 1.0 & 0.02 & 0.43 & -- & -- & 0.1 & $<0.33$ & nd \\
\hline HEDPA $(M)$ & -- & -- &..- & -- & 0.004 & nd & --- & --- & --- & --- & -- \\
\hline $\mathrm{NH}_{4} \mathrm{~F}(M)$ & - & -- & - & 0.2 & --- & -- & - & -- & $-\cdots$ & - & --- \\
\hline $\mathrm{Na}_{2} \mathrm{CO}_{3}(M)$ & -- & --- & -- & $--\cdot$ & --- & --- & 0.25 & nd & - & --- & --- \\
\hline $\mathrm{Ce}$ (ppm) & $4.90 \mathrm{E}+01$ & -- & $4.40 \mathrm{E}-01$ & -- & - & 6.14 & - & $<0.12$ & -- & $<0.12$ & 5.10 \\
\hline $\mathrm{Cr}$ (ppm) & $2.36 \mathrm{E}+02$ & -- & $2.09 E+02$ & $\cdots$ & $-\infty$ & $4.13 \mathrm{E}-01$ & - & $1.93 \mathrm{E}-01$ & -- & $1.42 \mathrm{E}-01$ & 2.24 \\
\hline $\mathrm{Fe}$ (ppm) & $5.97 E+02$ & --- & $4.94 E+02$ & --- & - & $1.94 \mathrm{E}+01$ & - & $6.75 \mathrm{E}-02$ & -- & $1.46 \mathrm{E}-01$ & $2.11 E+01$ \\
\hline $\mathrm{Zr}(\mathrm{ppm})$ & $1.44 \mathrm{E}+04$ & - & $7.43 E+03$ & $\cdots$ & -- & $2.24 \mathrm{E} \div 03$ & - & 1.70 & -- & 2.82E-01 & $2.08 \mathrm{E}+03$ \\
\hline${ }^{95} \mathrm{Zr}(\mathrm{dps} / \mathrm{mL})$ & $3.91 \mathrm{E}+01$ & - & $1.74 \mathrm{E}+01$ & - & $\ldots$ & 3.85 & - & $<0.67$ & --- & $<0.59$ & $<0.53$ \\
\hline${ }^{241} \mathrm{Am}(\mathrm{dps} / \mathrm{mL})$ & $7.36 \mathrm{E}+02$ & -- & $<4.48$ & - & -- & $6.03 \mathrm{E}+02$ & --- & $<2.58$ & -- & $<2.25$ & $<3.02$ \\
\hline Flowrate $(\mathrm{mL} / \mathrm{min})$ & 9.6 & 10.1 & 13.0 & 3.4 & 9.7 & 9.7 & 1.8 & 1.8 & 0.97 & 0.97 & 4.7 \\
\hline
\end{tabular}

not determined

Figure 5. TRUEX flowsheet test concentrations at shutdown. 
Table 4. Percentages of components in each of the effluent streams for TRUEX flowsheet testing.

\begin{tabular}{lccccccc}
\hline Stream & $\mathrm{Am}-241$ & $\mathrm{Zr}-95$ & $\mathrm{Zr}$ & $\mathrm{Ce}$ & $\mathrm{Cr}$ & $\mathrm{Fe}$ & $\mathrm{H}^{+}$ \\
\hline Aqueous & $<0.82 \%$ & $60.26 \%$ & $69.82 \%$ & $1.22 \%$ & $119.8 \%$ & $112.2 \%$ & $91.62 \%$ \\
Raffinate & $(<0.98 \%)^{\mathrm{a}}$ & $(83.58 \%)$ & $(69.31 \%)$ & $(4.89 \%)$ & $(99.01 \%)$ & $(94.12 \%)$ & $(83.31 \%)$ \\
Strip & $82.78 \%$ & $9.95 \%$ & $15.72 \%$ & $12.65 \%$ & $0.18 \%$ & $3.28 \%$ & $15.05 \%$ \\
Product & $(98.40 \%)$ & $(13.80 \%)$ & $(15.61 \%)$ & $(50.83 \%)$ & $(0.15 \%)$ & $(2.75 \%)$ & $(13.69 \%)$ \\
$\mathrm{Na}_{2} \mathrm{CO}_{3}$ & $<0.06 \%$ & $<0.31 \%$ & $0.002 \%$ & $<0.04 \%$ & $0.02 \%$ & $0.002 \%$ & $<2.12 \%$ \\
Effluent & $(<0.08 \%)$ & $(<0.43 \%)$ & $(0.002 \%)$ & $(<0.18 \%)$ & $(0.01 \%)$ & $(0.002 \%)$ & $(<1.93 \%)$ \\
$\mathrm{Na}_{2} \mathrm{CO}_{3}$ & $<0.03 \%$ & $<0.15 \%$ & $0.00 \%$ & $<0.02 \%$ & $0.01 \%$ & $0.002 \%$ & $<1.18 \%$ \\
Effluent & $(<0.04 \%)$ & $(<0.21 \%)$ & $(0.00 \%)$ & $(<0.10 \%)$ & $(0.01 \%)$ & $(0.002 \%)$ & $(<1.07 \%)$ \\
Solvent & $<0.43 \%$ & $<1.42 \%$ & $15.19 \%$ & $10.95 \%$ & $1.00 \%$ & $3.73 \%$ &. $\mathrm{nd}$ \\
Effluent & $(<0.51 \%)$ & $(<1.97 \%)$ & $(15.08 \%)$ & $(44.00 \%)$ & $(0.82 \%)$ & $(3.13 \%)$ & $\mathrm{nd}$ \\
Mass & $84.13 \%$ & $72.10 \%$ & $100.7 \%$ & $24.89 \%$ & $121.0 \%$ & $119.2 \%$ & $110.0 \%$ \\
Balance & & & & & & & \\
\hline
\end{tabular}

a. Normalized percentages.

b. The mass balance is the amount of a component accounted for based on the sample analysis results.

c. Not determined.

The results for total $\mathrm{Zr}$ and ${ }^{95} \mathrm{Zr}$ were expected to be the same since isotopic fractionation is not anticipated in the TRUEX process. The removal efficiency of $\mathrm{Zr}$ in the extraction section was $30.2 \%$, while that for ${ }^{95} \mathrm{Zr}$ was $39.7 \%$. These numbers compare reasonable well given the material balance discrepancy in the ${ }^{95} \mathrm{Zr}$ results, lending confidence to the assumption that the ${ }^{95} \mathrm{Zr}$ spike behaved similarly to the stable $\mathrm{Zr}$.

As anticipated, very little of the $\mathrm{Cr},<1 \%$, extracted into the TRUEX solvent. Some of the extracted Cr was recovered in the strip section $(-0.2 \%)$ and the balance $(-0.8 \%)$ appeared to remain in the organic effluent. This suggests that small amounts of $\mathrm{Cr}$ may build up in the organic phase. There is indeed a great deal of uncertainty associated with these numbers, but the apparent implication that $\mathrm{Cr}$ may build up in the TRUEX solvent will need evaluation in future tests.

There is also some uncertainty in the iron numbers due to the rather high material balance. The iron data, based on the normalized percentages, suggest that $~ 6 \%$ of the iron may have extracted into the solvent and approximately $3 \%$ was recovered in the strip. The remaining $3 \%$ of the iron remained in the organic effluent. As was previously noted, the Fe in the organic effluent was $21.1 \mathrm{ppm}$, while in the organic samples taken from stages 13,17 , and 19 the Fe was $<2.76 \mathrm{ppm}$. The reason for this discrepancy is not understood, but the data indicate less $\mathrm{Fe}$ may have carried over into the organic effluent than is indicated in Table 4. As with $\mathrm{Cr}$, the fate of iron and a determination of whether it actually builds up in the solvent must be addressed in future tests.

Stage-wise distribution coefficients were determined for several stages in different sections of the flowsheet and are listed in Table 5. The distribution coefficients for the various components are consistent with the results presented above for the percentages of the components found in each stream. Based on the distribution coefficients greater than one, ${ }^{241} \mathrm{Am}$ and $\mathrm{Ce}$ (albeit, to a lesser extent) extracted into the solvent in the extraction section and was not be removed in the scrub section. Although the data are less clear, particularly in stage 11 where the precipitate was heaviest, the Am and Ce distributions less than one indicate these components were re-extracted from the solvent in the strip section. Americium remaining in the solvent following the stripping section was slightly removed in the solvent wash and acid rinse sections. Cerium remaining in the solvent following stripping may or may not have been removed in the solvent wash and rinse sections. 
Table 5. Measured stage-wise distribution coefficients from TRUEX flowsheet testing.

\begin{tabular}{cllllllll}
\hline Stage & & $D_{\mathrm{Am}-241}$ & $\mathrm{D}_{\mathrm{Zr}-95}$ & $\mathrm{D}_{\mathrm{Zr}_{\mathrm{r}}}$ & $\mathrm{D}_{\mathrm{Ce}}$ & $\mathrm{D}_{\mathrm{Cr}}$ & $D_{\mathrm{Fe}}$ & $D_{\mathrm{H}^{+}}$ \\
\hline Extraction & 1 & $>1.72$ & 0.651 & 1.013 & 18.1 & 0.060 & 0.39 & 0.443 \\
& 3 & 6.31 & 0.645 & 0.679 & 4.00 & 0.019 & 0.203 & 0.302 \\
& 5 & 5.08 & 0.645 & 0.679 & 2.58 & 0.010 & 0.178 & 0.303 \\
Scrub & 6 & 4.60 & 0.550 & 0.717 & 2.74 & 0.011 & 0.176 & 0.305 \\
& 7 & 3.86 & 0.603 & 0.620 & 2.57 & 0.038 & 0.058 & 0.296 \\
Strip & 10 & 13.1 & 0.418 & 0.463 & 14.1 & 0.036 & 0.061 & 0.534 \\
& 11 & 8.18 & 0.910 & 1.40 & 9.07 & 1.01 & 0.095 & 1.39 \\
& 13 & $<0.037$ & nd $^{2}$ & 0.441 & $<0.29$ & 31.3 & 9.98 & nd \\
Wash & 16 & $<0.037$ & nd & nd & nd & nd & nd & nd \\
Rinse & 17 & nd & nd & 12.6 & $<3.73$ & 8.39 & 16.5 & nd \\
\hline
\end{tabular}

${ }^{2}$ Not determined

The distribution data for ${ }^{95} \mathrm{Zr}$ and total $\mathrm{Zr}$ are typically consistent, and indicate $\mathrm{Zr}$ was somewhat extracted by the solvent in the extraction section and scrubbed by the $\mathrm{NH}_{4} \mathrm{~F}$ solution. The zirconium was partially stripped from the solvent by the HEDPA. Any $\mathrm{Zr}$ remaining in the organic after stripping was not efficiently removed in the subsequent solvent wash or rinse sections. Favorable comparison of the distribution coefficients between ${ }^{95} \mathrm{Zr}$ and stable $\mathrm{Zr}$ in the extraction and scrub sections are a further indication that the tracer behavior is representative of that for bulk $\mathrm{Zr}$.

The distribution coefficient data indicate that the TRUEX solvent did not effectively extract $\mathrm{Cr}, \mathrm{Fe}$, or $\mathrm{H}^{+}$. The $\mathrm{Cr}$ and $\mathrm{Fe}$ that was not re-extracted from the solvent in the scrub section remained predominately in the solvent through the subsequent sections of the flowsheet. 


\section{CONCLUSIONS AND RECOMMENDATIONS}

\section{Conclusions}

Flooding and precipitate formation were observed in the strip section during the flowsheet testing. It is postulated that the flooding occurred as a result of precipitate formation. Until this problem is resolved, there is little utility in performing further counter-current flowsheet tests. The precipitate accumulated in the strip section stages and resulted in partial plugging of the light phase (organic) weirs. This resulted in organic carry over to the aqueous phase. The precipitate was determined to be $\mathrm{ZrPO}_{4}$ and was likely formed due the excessive amount of $\mathrm{Zr}$ carried into the strip section with the organic phase. In order to eliminate the precipitate, the amount of $\mathrm{Zr}$ extracted and carried over to the strip section must be limited. Reduction of $\mathrm{Zr}$ carryover may require adjustment of the feed to prevent or subdue $\mathrm{Zr}$ extraction, identification of alternative scrub reagent to more effectively remove $\mathrm{Zr}$ from the solvent, or identification of a different stripping reagent. Alternatively, an increase in the HEDPA concentration has been shown to alleviate the problem of precipitate formation, albeit with the undesirable effect of increasing the phosphate content in the HLW fraction. ${ }^{10}$

Despite the obvious problems encountered during the test, $>99.18 \%$ of the americium was removed from the feed in the extraction section. This may be slightly lower than the anticipated $99.9 \% \mathrm{Am}$ removal efficiency necessary to insure the $<10 \mathrm{nCi} / \mathrm{g}$ TRU content in the LLW raffinate. Approximately $95 \%$ of the Ce was extracted from the feed, which is somewhat less than anticipated based on the Am results

The results from the test indicate that little, if any improvement was observed from increasing the

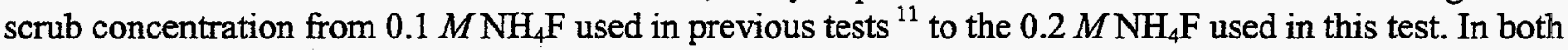
cases, roughly $65 \%$ of the $\mathrm{Zr}$ in the feed was removed. The primary difference was that the balance, or $\sim 33 \%$ of the $\mathrm{Zr}$ reported to the strip product (HLW fraction) in a previous test ${ }^{11}$, while $\sim 15 \%$ of the $\mathrm{Zr}$ reported to both the strip product and the organic effluent, respectively, indicating the strip section was ineffective at re-extracting $\mathrm{Zr}$. The results for $\mathrm{Ce}, \mathrm{Fe}$, and $\mathrm{Cr}$ in the strip section for this test were also consistent with the observations of $\mathrm{Zr}$, and $\sim 50 \%$ of the extracted metals reported to the strip product and rest remained in the solvent effluent. Changing the strip solution composition from that used in the previous test, $0.001 M$ HEDPA in $0.01 M \mathrm{HNO}_{3}$, to that used in this test, $0.004 M$ HEDPA in $0.02 \mathrm{M}$ $\mathrm{HNO}_{3}$, had no effect on eliminating the precipitate problem encountered in the stripping section. The poor strip section performance was probably due to the precipitation and concomitant flooding problems encountered in the test, resulting in the strip section never achieving steady state operating conditions.

\section{Recommendations}

Comparison of results from previous tests with those obtained in this experiment are indicative that the operating envelope may be too narrow in the proposed flowsheet to meet the desired objectives. Alternative methods for dealing with the problems encountered with TRUEX processing of dissolved $\mathrm{Zr}$ calcine are required. Recent tests indicate that the extraction of $\mathrm{Zr}$ may be suppressed by lowering the acid concentration in the dissolved calcine feed. The previous baseline dissolution scheme used $5 M \mathrm{HNO}_{3}$ with a final acid concentration in the dissolver solution of $\sim 3.5 \mathrm{M} \mathrm{H}^{+}$. Acidity reduction of the dissolved calcine feed solution is currently being evaluated by alternative dissolution schemes. In fact, the current recommendation is to use $3 \mathrm{MHNO}_{3}$ as the dissolvent, which reduces the acidity of the dissolved calcine solution to $\sim 1.2 \mathrm{M} \mathrm{H}^{+}$. Preliminary data obtained in batch contacts indicate this minor change will significantly reduce the amount of $\mathrm{Zr}$ extracted into the TRUEX solvent. Recent testing of citric acid addition to the dissolved calcine feed indicates this may be a viable $\mathrm{Zr}$ complexant in the $\mathrm{Zr}$ calcine matrix. Further evaluations are planned and recommended to evaluate the use of citrate for feed adjustment and as a scrub solution. 


\section{REFERENCES}

1. J. R. Berreth, "Inventories and Properties of ICPP Calcined High-Level Waste", WINCO-1050, February 1988.

2. J. A. Murphy, L. F. Pincock, and I. N. Christiansen, ICPP Radioactive Liquid and Calcine Waste Technologies Evaluation Final Report and Recommendation, INEL-94/0119, April 1995.

3. A. L Olson, W. W. Schulz, L. A. Burchfield, C. D. Carlson, J. L. Swanson, and M. C. Thompson, Evaluation and Selection of Aqueous Based Technology for Partitioning Radionuclides from ICPP Calcine, WINCO-1071, February 1993.

4. E. P. Horwitz, et al., Solvent Extr. \& Ion Exch., 3(1\&2), 75, 1985.

5. W. W. Schulz and E. P. Horwitz, Sep. Science \& Technology, 23(12 \& 13), 1191-1210, (1988).

6. R. S. Herbst, K. N. Brewer, T. J. Tranter, and T. A. Todd, TRUEX Partitioning from Radioactive ICPP Sodium Bearing Waste, INEL-95/0224, March 1995.

7. J. D. Law and R. S. Herbst, TRUEX Flowsheet Development as Applied to ICPP Sodium-Bearing Waste Using Centrifugal Contactors, INEL-95/0130, February 1995.

8. R. S. Herbst, D. S. Fryer, K. N. Brewer, C. K. Johnson, and T. A. Todd, Experimental Results: Pilot Plant Calcine Dissolution and Liquid Feed Stability, INEL-95/0097, February 1995.

9. K. N. Brewer, A. L. Olson, W. S. Roesener, and J. L. Tonso, Experimental Results of Calcine Studies Performed During FY-94,95, INEEL/EXT-97-01192, September 1997.

10. K. N. Brewer, et al., Elimination of Phosphate and Zirconium in the High-Activity Fraction Resulting From TRUEX Partitioning of ICPP Zirconium Calcines, INEEL/EXT-97-00836, July 1997.

11. K. N. Brewer, R. S. Herbst, et al., TRUEX Process Applied To Radioactive Idaho Chemical Processing Plant High Level Waste Calcine, Proceedings of the International Topical Meeting on Nuclear and Hazardous Waste Management, SPECTRUM '96, Seattle, WA, August 18-23, 1996.

12. R. Chiarzia and E. P. Horwitz, Solvent Extr. \& Ion Exch., $\underline{8}(6), 907,1990$.

13. K. N. Brewer, R. S. Herbst, T. J. Tranter, and T. A. Todd, CMPO Purity Tests in the TRUEX Solvent Using Americium-241, WINCO-1177, December 1993. 
Appendix A

Experimental Data 
Table A-1. Approach to steady state sample concentrations.

\begin{tabular}{cccccccc}
\hline $\begin{array}{c}\text { Sample } \\
\text { Lable }\end{array}$ & $\begin{array}{c}\mathrm{Am}-241 \\
(\mathrm{dps} / \mathrm{mL})\end{array}$ & $\begin{array}{c}\mathrm{Zr}-95 \\
(\mathrm{dps} / \mathrm{mL})\end{array}$ & $\begin{array}{c}\mathrm{Zr} \\
(\mathrm{ppm})\end{array}$ & $\begin{array}{c}\mathrm{Ce} \\
(\mathrm{ppm})\end{array}$ & $\begin{array}{c}\mathrm{Cr} \\
(\mathrm{ppm})\end{array}$ & $\begin{array}{c}\mathrm{Fe} \\
(\mathrm{ppm})\end{array}$ & $\begin{array}{c}\mathrm{H}^{+} \\
(\mathrm{M})\end{array}$ \\
\hline AQ FEED & $7.36 \mathrm{E}+02$ & $3.91 \mathrm{E}+01$ & $1.44 \mathrm{E}+04$ & $4.90 \mathrm{E}+01$ & $2.36 \mathrm{E}+02$ & $5.97 \mathrm{E}+02$ & $2.86 \mathrm{E}+00$ \\
$1 \mathrm{Aq}-30$ & $<3.63$ & $1.65 \mathrm{E}+01$ & & & & & \\
$1 \mathrm{Aq}-60$ & $<4.94$ & $1.60 \mathrm{E}+01$ & & & & & \\
$1 \mathrm{Aq}-90$ & $<4.00$ & $1.68 \mathrm{E}+01$ & & & & & \\
$11 \mathrm{Aq}-30$ & $2.13 \mathrm{E}+02$ & $3.04 \mathrm{E}+00$ & & & & & \\
$11 \mathrm{Aq}-60$ & $3.23 \mathrm{E}+02$ & $5.78 \mathrm{E}+00$ & & & & & \\
$11 \mathrm{Aq}-90$ & $1.17 \mathrm{E}+03$ & $7.97 \mathrm{E}+00$ & & & & & \\
\hline
\end{tabular}

Labelling scheme: Stage\#/ phase-time

Table A-2. Effluent samples taken just prior to shutdown.

\begin{tabular}{cccccccc}
\hline Sample & $\begin{array}{c}\mathrm{Am}-241 \\
(\mathrm{dps} / \mathrm{mL})\end{array}$ & $\begin{array}{c}\mathrm{Zr}-95 \\
(\mathrm{dps} / \mathrm{mL})\end{array}$ & $\begin{array}{c}\mathrm{Zr} \\
(\mathrm{ppm})\end{array}$ & $\begin{array}{c}\mathrm{Ce} \\
(\mathrm{ppm})\end{array}$ & $\begin{array}{c}\mathrm{Cr} \\
(\mathrm{ppm})\end{array}$ & $\begin{array}{c}\mathrm{Fe} \\
(\mathrm{ppm})\end{array}$ & $\mathrm{H}+(\mathrm{M})$ \\
\hline 1aq-Prod & $<4.48$ & $1.74 \mathrm{E}+01$ & $7.43 \mathrm{E}+03$ & $4.40 \mathrm{E}-01$ & $2.09 \mathrm{E}+02$ & $4.94 \mathrm{E}+02$ & 1.935 \\
1 laq-Prod & $6.03 \mathrm{E}+02$ & $3.85 \mathrm{E}+00$ & $2.24 \mathrm{E}+03$ & $6.14 \mathrm{E}+00$ & $4.13 \mathrm{E}-01$ & $1.94 \mathrm{E}+01$ & 0.426 \\
17aq-Prod & $<2.58$ & $<0.67$ & $1.70 \mathrm{E}+00$ & $<0.12$ & $1.93 \mathrm{E}-01$ & $6.75 \mathrm{E}-02$ & $<0.33$ \\
19aq-Prod & $<2.25$ & $<0.59$ & $2.82 \mathrm{E}-01$ & $<0.12$ & $1.42 \mathrm{E}-01$ & $1.46 \mathrm{E}-01$ & $<0.33$ \\
20or-Prod & $<3.02$ & $<0.53$ & $2.08 \mathrm{E}+03$ & $5.10 \mathrm{E}+00$ & $2.24 \mathrm{E}+00$ & $2.11 \mathrm{E}+01$ & $\mathrm{nd}^{2}$ \\
\hline
\end{tabular}

${ }^{2}$ Not determined 
Table A-3. Sample data for the individual contactor stages after phase re-equilibration.

\begin{tabular}{|c|c|c|c|c|c|c|c|c|}
\hline Description & Sample & $\begin{array}{c}\mathrm{Am}-241 \\
(\mathrm{dps} / \mathrm{mL})\end{array}$ & $\begin{array}{c}\mathrm{Zr}-95 \\
(\mathrm{dps} / \mathrm{mL})\end{array}$ & $\begin{array}{c}\mathrm{Zr} \\
(\mathrm{ppm})\end{array}$ & $\begin{array}{c}\mathrm{Ce} \\
(\mathrm{ppm})\end{array}$ & $\begin{array}{c}\mathrm{Cr} \\
(\mathrm{ppm})\end{array}$ & $\begin{array}{c}\mathrm{Fe} \\
(\mathrm{ppm})\end{array}$ & $\begin{array}{l}\mathrm{H}^{+} \\
(\mathrm{M})\end{array}$ \\
\hline \multirow{8}{*}{ EXTRACTION } & 1or & $6.56 \mathrm{E}+00$ & $9.70 \mathrm{E}+00$ & $9.54 \mathrm{E}+03$ & $3.87 \mathrm{E}+01$ & $1.29 \mathrm{E}+01$ & $2.08 \mathrm{E}+02$ & 0.927 \\
\hline & $1 \mathrm{aq}$ & $<3.81$ & $1.49 E+01$ & $9.41 E+03$ & $2.14 \mathrm{E}+00$ & $2.27 E+02$ & $5.30 \mathrm{E}+02$ & 2.093 \\
\hline & 3 or & $4.34 \mathrm{E}+01$ & $1.60 \mathrm{E}+01$ & 9554.6 & $3.03 \mathrm{E}+01$ & $4.14 \mathrm{E}+00$ & $1.15 E+02$ & 0.866 \\
\hline & $3 a q$ & $6.88 \mathrm{E}+00$ & $2.48 E+01$ & $1.41 \mathrm{E}+04$ & $7.57 \mathrm{E}+00$ & $2.17 \mathrm{E}+02$ & $5.68 \mathrm{E}+02$ & 2.866 \\
\hline & 5or & $3.03 E+02$ & $1.82 \mathrm{E}+01$ & $1.05 E+04$ & $5.37 \mathrm{E}+01$ & $2.30 \mathrm{E}+00$ & $1.02 \mathrm{E}+02$ & 0.862 \\
\hline & $5 \mathrm{aq}$ & $5.97 \mathrm{E}+01$ & $2.82 \mathrm{E}+01$ & $1.51 E+04$ & $2.08 \mathrm{E}+01$ & $2.27 \mathrm{E}+02$ & $5.72 E+02$ & 2.846 \\
\hline & 6 or & $6.76 \mathrm{E}+02$ & $1.69 \mathrm{E}+01$ & $1.08 E+04$ & $7.47 \mathrm{E}+01$ & $2.32 \mathrm{E}+00$ & $9.85 \mathrm{E}+01$ & 0.870 \\
\hline & $6 \mathrm{aq}$ & $1.47 \mathrm{E}+02$ & $3.07 \mathrm{E}+01$ & $1.50 \mathrm{E}+04$ & $2.73 E+01$ & $2.18 E+02$ & $5.59 \mathrm{E}+02$ & 2.855 \\
\hline \multirow[t]{4}{*}{ SCRUB } & 7 or & $7.76 \mathrm{E}+02$ & $1.90 \mathrm{E}+01$ & $9.27 \mathrm{E}+03$ & $6.61 \mathrm{E}+01$ & $2.27 \mathrm{E}+00$ & $2.71 \mathrm{E}+01$ & $\overline{0.825}$ \\
\hline & $7 a q$ & $2.01 E+02$ & $3.15 E+01$ & $1.50 E+04$ & $2.57 \mathrm{E}+01$ & $5.97 \mathrm{E}+01$ & $4.65 E+02$ & 2.784 \\
\hline & 10 or & $6.50 \mathrm{E}+02$ & $9.96 E+00$ & $5.01 \mathrm{E}+03$ & $5.17 \mathrm{E}+01$ & $2.41 \mathrm{E}+00$ & $2.11 E+01$ & 0.753 \\
\hline & $10 \mathrm{aq}$ & $4.97 \mathrm{E}+01$ & $2.38 \mathrm{E}+01$ & $1.08 \mathrm{E}+04$ & $3.65 \mathrm{E}+00$ & $6.67 \mathrm{E}+01$ & $3.45 \mathrm{E}+02$ & 1.411 \\
\hline \multirow[t]{6}{*}{ STRIP } & 11 or & $5.87 \mathrm{E}+02$ & $3.66 \mathrm{E}+00$ & $2.91 \mathrm{E}+03$ & $4.60 \mathrm{E}+01$ & $2.28 \mathrm{E}+00$ & $2.01 \mathrm{E}+00$ & $\overline{0.653}$ \\
\hline & $11 a q$ & $7.18 \mathrm{E}+01$ & $4.02 E+00$ & $2.08 \mathrm{E}+03$ & $5.07 \mathrm{E}+00$ & $2.25 \mathrm{E}+00$ & $2.11 E+01$ & 0.471 \\
\hline & 13 or & $<2.06$ & $<0.76$ & $6.48 \mathrm{E} \div 01$ & $<0.79$ & $2.41 \mathrm{E}+00$ & $1.97 \mathrm{E}+00$ & 0.623 \\
\hline & $13 \mathrm{aq}$ & $5.52 \mathrm{E}+01$ & $<0.75$ & $1.47 \mathrm{E}+02$ & $2.75 \mathrm{E}+00$ & $7.70 \mathrm{E}-02$ & $1.98 \mathrm{E}-01$ & $<0.33$ \\
\hline & 16 or & $<2.15$ & $<0.63$ & $\mathrm{nd}^{\mathrm{a}}$ & nd & nd & nd & nd \\
\hline & $16 a q$ & $5.87 \mathrm{E}+01$ & $<0.67$ & $6.64 \mathrm{E}+01$ & $3.78 \mathrm{E}+00$ & $3.55 \mathrm{E}-02$ & $1.38 \mathrm{E}-01$ & $<0.33$ \\
\hline \multirow[t]{2}{*}{$\mathrm{Na}_{2} \mathrm{CO}_{3}$ WASH } & 17or & $<2.13$ & $<0.69$ & $4.79 \mathrm{E}+01$ & $<0.79$ & $2.76 \mathrm{E}+00$ & $1.25 \mathrm{E}+00$ & $\overline{0.648}$ \\
\hline & $17 \mathrm{aq}$ & $<2.43$ & $<0.64$ & $3.79 E+00$ & $2.12 \mathrm{E}-01$ & $3.29 \mathrm{E}-01$ & $7.55 \mathrm{E}-02$ & $<0.33$ \\
\hline \multirow[t]{2}{*}{$\mathrm{HNO}_{3} \mathrm{RINSE}$} & 19 or & $<2.58$ & $<0.58$ & $2.98 \mathrm{E}+01$ & $<0.79$ & $2.46 \mathrm{E}+00$ & $1.32 \mathrm{E}+00$ & $\overline{0.649}$ \\
\hline & $19 a q$ & $<2.61$ & $<0.63$ & $<0.05$ & $6.50 \mathrm{E}-02$ & $1.68 \mathrm{E}-01$ & $1.95 \mathrm{E}-01$ & $<0.33$ \\
\hline
\end{tabular}

${ }^{2}$ Not Determined 